\title{
PENGARUH PEMBERIAN PELATIHAN, FASILITAS DAN KOMPENSASI TERHADAP MOTIVASI KERJA PEGAWAI BADAN PENGELOLA KEUANGAN DAN ASET DAERAH KABUPATEN BATU BARA
}

\author{
${ }^{1}$ Evi Rafda Aryani, ${ }^{2}$ Iin Erpianto, ${ }^{3}$ Ahmad Irwan Pulungan, ${ }^{4}$ Riono Asnan Lubis, ${ }^{5}$ Siti Saroh \\ $1,2,3,4,5$ Universitas Islam Sumatera Utara \\ Ievi.rafda@gmail.com, ${ }^{2}$ iin.erpianto@gmail.com, ${ }^{3}$ ahmad.irwan@gmail.com, ${ }^{4}$ riono.asnan@gmail.com, \\ ${ }^{5}$ siti.saroh@gmail.com
}

\begin{abstract}
The formulation of the problem in this study is: How is the effect of training, facilities and compensation on employee motivation. This study aims to determine the effect of training, facilities and compensation on employee motivation. With the Total Sampling technique, the sample in this study was 65 people. Training partially have a positive effect on employee work motivation; Facilities partially have a positive effect on employee work motivation; Compensation partially have a positive effect on employee work motivation; Training, facilities and compensation simultaneously have a positive and significant effect on employee work motivation.
\end{abstract}

Keywords : Training; Facility; Compensation; Work motivation

ABSTRAK : Rumusan masalah dalam penelitian ini adalah : Bagaimana pengaruh pelatihan, fasilitas dan kompensasi terhadap motivasi kerja pegawai. Penelitian ini bertujuan untuk mengetahui pengaruh pelatihan, fasilitas dan kompensasi terhadap motivasi kerja pegawai. Dengan teknik Total Sampling maka sampel dalam penelitian ini sebanyak 65 orang. Pelatihan secara parsial berpengaruh positif terhadap motivasi kerja pegawai; Fasilitas secara parsial berpengaruh positif terhadap motivasi kerja pegawai; Kompensasi secara parsial berpengaruh positif terhadap motivasi kerja pegawai; Pelatihan, fasilitas dan kompensasi secara simultan berpengaruh positif dan signifikan terhadap motivasi kerja pegawai.

Kata Kunci : Pelatihan; Fasilitas; Kompensasi; Motivasi Kerja

\section{Pendahuluan}

Pegawai dalam suatu organisasi merupakan salah satu faktor yang sangat mempengaruhi keberhasilan organisasi dalam mencapai tujuannya. Pegawai bukan semata objek dalam pencapaian tujaun organisasi, tetapi juga menjadi subjek/pelaku. Pegawai dapat menjadi perencana, pelaksana dan pengendali yang selalu berperan aktif dalam pencapaian tujuan organisasi, serta mempunyai pikiran, perasaan dan keinginan yang dapat mempengaruhi sikapnya dalam pekerjaan. Selain itu, pegawai memberikan kontribusi kepada organisasi berupa kemampuan, keahlian dan keterampilan yang dimiliki, sedangkan organisasi diharapkan memberikan imbalan dan pengharagaan kepada pegawai secara adil sehingga dapat memberikan motivasi kerja.

Motivasi untuk bekerja sangat penting bagi tinggi rendahnya produktivitas suatu instansi atau organisasi. Tanpa adanya motivasi dari para pegawai untuk bekerja sama bagi kepentingan organisasi/instansi maka tujuan yang telah ditetapkan tidak akan tercapai. Sebaliknya, apabila terdapat motivasi yang tinggidari para pegawai, maka hal ini merupakan suatu jaminan atas keberhasilan instansi/organisasi dalam mencapai tujuannya.

Berdasarkan observasi dan wawancara dengan beberapa orang pegawai pada Kantor Badan Pengelola Keuangan Dan Aset Daerah Kabupaten Batu Bara, ditemukan beberapa fenomena motivasi kerja pegawai sebagai berikut :

1) Masih ada pegawai yang bermalas malasan dalam bekerja sehingga lebih banyak bersantai daripada bekerja

2) Masih ada pegawai mendahulukan kepentingan pribadi daripada kepentingan kantor dalam melaksanakan tugasnya 
3) Jika ada kesalahan dalam bekerja, pegawai kurang inisiatif untuk memperbaikinya,

4) Masih kurangnya pegawai memunculkan ide-ide baru penyelesaian tugas.

5) Masih ada pegawai melaksanakan tugasnya tidak bersungguh-sungguh dan kurang teliti dalam bekerja

6) Masih ada sebagian pegawai pada saat bekerja pegawai sering menunda- nunda pekerjaannya,

7) Masih ada sebagian pegawai yang datang terlambat dan pulang lebih awal serta adanya pegawai yang keluar masuk kantor pada saat jam kerja, dan

8) Masih ada sebagian pegawai yang tidak menyelesaikan pekerjaannya tepat pada waktunya.

\begin{tabular}{lcr}
\multicolumn{1}{c}{ Disini terlihat masih } & kurangnya \\
tanggung jawab, inisiatif & dalam \\
menyelesaikan pekerjaan dan kreatif \\
dalam $\quad$ melaksanakan & pekerjaannya
\end{tabular}

(Yancomala, 2014 : 82).

Motivasi kerja merupakan sesuatu yang sangat dibutuhkan setiap individu untuk mencapai target atau hal yang dicapai dari pekerjaan tersebut. Dimana motivasi kerja ini membuat setiap individu menjadi semangat atau mempunyai dorongan untuk mempengaruhi setiap individu dalam bekerja. Sesuai dengan pendapat Hasibuan (2012: 84) motivasi penting karena motivasi adalah hal yang menyebabkan, menyalurkan, dan mendukung perilaku manusia supaya mau bekerja giat dan antusias mencapai hasil yang optimal.

Hal ini dapat dilihat dari fenomena seperti Fenomena yang ada masih terdapat pegawai dalam bekerja mengalami penurunan motivasi kerja atau rendahnya motivasi kerja dapat ditunjukkan dengan keterlambatan pegawai yang merupakan penurunan terhadap kedisipilan kerja cerminan dari rendahnya motivasi kerja seorang pegawai dengan pekerjaannya. Peningkatan tingkat keterlambatan pegawai dapat disebabkan oleh kurang semangat atau kurang bergairah pegawai untuk masuk kerja. Rendahnya motivasi kerja disebabkan kurangnya disiplin pegawai dalam melaksanakan pekerjaan. Pegawai sering datang terlambat pada jam masuk kantor, hal ini disebabkan kurangnya peraturan yang tegas bagi pegawai dalam melaksanakan pekerjaannya.
Permasalahan ini ditunjukkan oleh indikasi bahwa sebahagian pegawai kurang memiliki kebutuhan untuk meraih prestasi dalam bekerja, dimana kebanyakan pegawai datang ke kantor hanyalah untuk melaksanakan rutinitas sehari-hari tanpa mengutamakan pencapaian prestasi yang tinggi dalam bekerja. Selain itu menurut hasil wawancara yang dilakukan oleh peneliti kepada subjek berinisial $\mathrm{H}$, bahwa subjek tersebut menyatakan bahwa motivasi kerja yang dimiliki pegawai masih dibilang rendah hal ini dinyatakan saat kegiatan rapat bersama dalam rangka untuk membahas suatu permasalahan agar mendapatkan jalan keluar dari permasalahan tersebut, tetapi kenyataannya saat rapat berlangsung pegawai hanya pasif duduk terdiam terkadang ada pegawai memainkan ponsel pribadi masingmasing. Sehingga ketika ada waktu untuk memberikan kebebasan untuk mengeluarkan pendapat, pegawai tidak mengeluarkan pendapatnya apapun dan terkadang rapat tersebut berakhir dengan tangan kosong. Dari wawancara tersebut terdapat 45 orang yang pasif saat berlangsung dan hanya seputar pegawai tersebut yang pasif ketika rapat berlangsung tetapi pegawai lain yang aktif dalam rapat berkisar 21 orang.

Rendahnya motivasi kerja pegawai diduga dipengaruhi oleh banyak faktor, salah satunya adalah fasilitas kerja. Agar pegawai yang berada di dalam organisasi dapat bekerja dengan baik dan memberikan hasil yang maksimal, maka perlu memperhatikan kebutuhan, keinginan, dan harapan pegawai atas pekerjaan yang mereka lakukan. Dengan terpenuhinya kebutuhan dan harapan tersebut maka pegawai akan merasa puas dan termotivasi dalam melakukan pekerjaannya. Fasilitas kerja pada pengamatan penulis di lapangan kurang kondusif. Hal ini disebabkan karena terdapat lay out kantor tidak bagus (sempit dan sesak), tidak terdapat gudang penyimpanan yang mencukupi arsip-arsip sehingga terkesan berserakan serta menimbulkan ketidak nyamanan dalam bekerja, ketersediaan peralatan kerja kantor yang sudah lama dan tidak terawat kondisinya. Kondisi ruangan yang berukuran kecil dan sempit yang tidak sebanding dengan banyaknya pegawai menyebabkan tidak leluasanya pegawai dalam bekerja. Fasilitas yang tidak mendukung pegawai dalam bekerja menyebabkan terhambatnya pegawai dalam melaksanakan pekerjaannya dan hal ini membuat pegawai kurang semangat dalam bekerja. 
Rendahnya motivasi kerja pegawai diduga dipengaruhi oleh banyak faktor, salah satunya lingkungan kerja. Menurut Husnan (2012; 43), fasilitas kerja adalah sarana dan prasarana yang diperlukan untuk membantu pegawai agar lebih mudah menyelesaikan pekerjaan sehingga dapat meningkatkan kinerjanya. Fasilitas kerja merupakan segala sesuatu yang ada di sekitar pegawai pada saat bekerja baik fisik maupun nonfisik yang dapat mempengaruhi dirinya dan pekerjaanya. Fasilitas kerja yang baik memungkinkan pegawai bekerja lebih bersemangat sehingga hasil kerjanya lebih memuaskan. Fasilitas kerja ini mampu memberikan dan meningkatkan motivasi kerja pegawai karena fasilitas kerja mempunyai pengaruh terhadap pegawai yang melaksanakan pekerjaan.

Selanjutnya menurut Sonny dalam Sinambela (2016:169) "Pendidikan dan pelatihan merupakan salah satu faktor yang penting dalam pengembangan sumber daya manusia. Pendidikan dan latihan tidak hanya menambah pengetahuan, tetapi juga meningkatkan keterampilan bekerja sehingga meningkatkan produktivitas kerja". Sedangkan pelatihan menurut Monday (2018:210) adalah aktifitas yang dirancang untuk pembelajaran, pengetahuan, dan keterampilan, yang dibutuhkan untuk pekerjaan saat ini. Berdasarkan pendapat para pakar diatas, maka pengertian pelatihan adalah suatu proses didalam suatu instansi untuk memperbaiki kinerja pegawainya.

Upaya meningkatkan kinerja pegawai dalam organisasi melalui pendidikan dan pelatihan merupakan salah satu hal yang harus dilakukan dan mendapat perhatian yang serius dalam rangka menjawab berbagai tantangan dan perubahan yang terjadi dalam masyarakat, sekaligus untuk meningkatkan kinerja organisasi.

Pelatihan merupakan bagian dari investasi sumber daya manusia untuk meningkatkan kemampuan dan eterampilan kerja karna dengan demikian dapat meningkatan kinerja pegawai Mangkunegra (2012:30). Hal senada juga tertulis dalam peraturan pemerintah No. 101 tahun 2010 tentang diklat jabatan PNS yaitu pendidikan dan pelatihan didefenisikan sebagai proses penyelenggaraan belajar mengajar dalam ranga meningkatkan kinerja PNS.

Pelatihan adalah suatu kegiatan yang dilakukan instansi dengan maksud untuk dapat memperbaiki dan mengembangkan sikap, tingkah laku, keterampilan dan pengetahuan dari parapegawai sesuai dengan keinginan dari instansi yang bersangkutan. Pelatihan berhubungan dengan penambahan pengetahuan umum. Pengertian tentang pelatihan adalah tindakan untuk meningkatkan pengetahuan, dan kecakapan seorang pegawai untuk melaksanakan pekerjaan tertentu

Berdasarkan beberapa fenomena di atas bahwa fasilitas kerja yang baik akan dapat menimbulkan suasana kerja yang dapat membuat pegawai bekerja lebih giat dan secara otomatis juga dapat meningkatkan motivasi kerja pegawai yang berdampak langsung pada produktifitas kerja pegawai. Apabila pegawai merasa puas dengan fasilitas kerjanya, maka pegawai akan dapat mengatasi tekanan-tekanan yang dihadapi, sehingga pegawai akan cenderung menyukai pekerjaan dan bersemangat dalam melaksanakannya, tetapi bila pegawai merasa fasilitas kurang mendukung, maka pegawai akan mengalami tekanan dalam bekerja.

\subsection{Batasan Masalah}

Agar permasalahan yang dikaji terarah maka permasalahan dibatasi sebagai berikut. Penelitian ini hanya membahas tentang pengaruh pelatihan, fasilitas kerja dan kompensasi terhadap motivasi kerja.

\subsection{Rumusan Masalah}

Setiap instansi pasti mempunyai masalah yang berbeda-beda dengan instansi lainnya. Adanya perubahan yang selalu dihadapi oleh setiap instansi baik yang berada diluar maupun didalam instansi tersebut dapat menjadi hambatan demi pencapaian tujuan yang efektif dan efisien.

Bedasarkan latar belakang masalah tersebut diatas, maka yang menjadi rumusan masalah dalam penelitian ini adalah :

a. Bagaimana pengaruh pelatihan terhadap motivasi kerja pegawai Badan Pengelola Keuangan Dan Aset Daerah Kabupaten Batu Bara

b. Bagaimana pengaruh fasilitas terhadap motivasi kerja pegawai Badan Pengelola Keuangan Dan Aset Daerah Kabupaten Batu Bara

c. Bagaimana pengaruh kompensasi terhadap motivasi kerja pegawai Badan Pengelola Keuangan Dan Aset Daerah Kabupaten Batu Bara 
d. Bagaimana pengaruh pelatihan, fasilitas dan kompensasi terhadap motivasi kerja pegawai Badan Pengelola Keuangan Dan Aset Daerah Kabupaten Batu Bara.

\subsection{Tujuan Penelitian}

Tujuan penelitian ini adalah :

a. Untuk mengetahui pengaruh pelatihan terhadap motivasi kerja pegawai Badan Pengelola Keuangan Dan Aset Daerah Kabupaten Batu Bara

b. Untuk mengetahui pengaruh fasilitas terhadap motivasi kerja pegawai Badan Pengelola Keuangan Dan Aset Daerah Kabupaten Batu Bara

c. Untuk mengetahui pengaruh kompensasi terhadap motivasi kerja pegawai Badan Pengelola Keuangan Dan Aset Daerah Kabupaten Batu Bara

d. Untuk mengetahui pengaruh pelatihan, fasilitas dan kompensasi terhadap motivasi kerja pegawai Badan Pengelola Keuangan Dan Aset Daerah Kabupaten Batu Bara.

\section{Metode Penelitian}

\subsection{Populasi}

Dalam suatu penelitian, populasi yang dipilih mempunyai hubungan yang erat dengan masalah yang diteliti. Populasi atau unverse adalah jumlah keseluruhan unit analisis yang ciricirinya akan diduga, Singarimbun \& Effendi (2012 : 126). Dalam penelitian ini yang menjadi populasi adalah seluruh pegawai Badan Pengelola Keuangan Dan Aset Daerah Kabupaten Batu Bara yang berjumlah 66 orang kerena Kepala Badan Posisinya masih Plt. Sehingga tidak dijadikan populasi dan dapat dijelaskan dengan kerangka populasi sebagai berikut :

Tabel 1. Kerangka Populasi Berdasarkan Jabatan Thn. 2021

\begin{tabular}{|r|l|r|}
\hline No & Jabatan & Jlh Populasi \\
\hline 1 & Sekretaris & 1 \\
\hline 2 & Ka. Bidang & 4 \\
\hline 3 & Ka. Sub Bag & 3 \\
\hline 4 & Ka. Sub Bid & 9 \\
\hline 5 & Penata & 1 \\
\hline 6 & Analis & 2 \\
\hline 7 & Penyusun & 1 \\
\hline 8 & Pengelola & 8 \\
\hline 9 & Pengadministrasi & 8 \\
\hline 10 & Operator & 12 \\
\hline 11 & Adminstrasi Kantor & 11 \\
\hline
\end{tabular}

\begin{tabular}{|c|l|r|}
\hline No & Jabatan & Jlh Populasi \\
\hline 12 & Petugas Kantor & 6 \\
\hline Jumlah & $\mathbf{6 6}$ \\
\hline \multicolumn{3}{|c|}{ Sumber: Badan Pengelola Keuangan Dan } \\
Aset Daerah Kabupaten Batu Bara -2021
\end{tabular}

\subsection{Sampel}

Sampel merupakan bagian dari elemenelemen populasi yang hendak diteliti. Adapun ide dasar dari pengambilan sampel adalah bahwa dengan menyeleksi bagian dari elelmenelemen populasi, kesimpulan tentang keseluruhan populasi diharapkan dapat diperoleh, Cooper \& Pamela (2011 : 95). Keunggulan ekonomis pengambilan sampel adalah biayanya lebih murah dan memberikan hasil yang lebih cepat. Dengan teknik penarikan sampel secara Total Sampling maka sampel dalam penelitian ini adalah seluruh populasi yaitu pegawai Badan Pengelola Keuangan Dan Aset Daerah Kabupaten Batu Bara sebanyak 65 orang. Karena peneliti sebagai Ka.Sub Bid Pelaporan tidak ikut dalam penelitian ini.

\section{Hasil Dan Pembahasan Hasil Penelitian 3.1. Uji Validitas}

Suatu instrumen yang valid atau sahih mempunyai validitas yang tinggi. Sebaliknya instrumen yang kurang valid berarti memiliki validitas rendah (Arikunto, 2014:160). Sebelum dilakukan pengumpulan data, pertanyaan di dalam kuesioner diuji terlebih dahulu untuk mengetahui validitas dan reliabilitasnya. Cara pengukurannya menggunakan SPSS Versi 24.00 , untuk mengetahui setiap butir pernyataan valid atau tidak valid yaitu dengan syarat:

a. Jika $r$ hitung $\geq r$ tabel dengan signifikasi 95\%, maka instrumen tersebut dinyatakan valid.

b. Jika $\mathrm{r}$ hitung $\leq \mathrm{r}$ tabel dengan signifikasi 95\%, maka instrumen tersebut dinyatakan tidak valid (Sugiyono, 2015:213). Nilai $\mathrm{r}$ hitung untuk pengujian ini dapat diketahui melalui hasil pengolahan data melalui SPSS versi 24.00 ( lihat lampiran). Sedangkan nilai $r$ tabel untuk $n=65$ dan taraf kesalahan $(\alpha) 0,05 \%$ adalah sebesar 0,244 $(\mathrm{db}=$ n-2). Dari proses uji validitas yang dilakukan terhadap 65 responden tersebut, maka hasil yang diringkas dapat ditunjukkan pada tabel berikut: Table 2. Hasil Uji Validitas Variabel (X1). 
Table 2. Hasil Uji Validitas Variabel $\left(\mathrm{X}_{1}\right)$

\begin{tabular}{|c|c|c|c|}
\hline Nomor Soal & rhitung & rtabel & Keterangan \\
\hline 1 & 0,414 & 0,244 & Valid \\
\hline 2 & 0,522 & 0,244 & Valid \\
\hline 3 & 0,763 & 0,244 & Valid \\
\hline 4 & 0,761 & 0,244 & Valid \\
\hline 5 & 0,623 & 0,244 & Valid \\
\hline 6 & 0,429 & 0,244 & Valid \\
\hline 7 & 0,770 & 0,244 & Valid \\
\hline 8 & 0,763 & 0,244 & Valid \\
\hline 9 & 0,461 & 0,244 & Valid \\
\hline 10 & 0,521 & 0,244 & \\
\hline
\end{tabular}

Table 3. Hasil Uji Validitas Variabel $\left(\mathrm{X}_{2}\right)$

\begin{tabular}{|c|c|c|c|}
\hline Nomor Soal & rhitung & rtabel & Keterangan \\
\hline 1 & 0,281 & 0,244 & Valid \\
\hline 2 & 0,530 & 0,244 & Valid \\
\hline 3 & 0,746 & 0,244 & Valid \\
\hline 4 & 0,746 & 0,244 & Valid \\
\hline 5 & 0,618 & 0,244 & Valid \\
\hline 6 & 0,281 & 0,244 & Valid \\
\hline 7 & 0,609 & 0,244 & Valid \\
\hline 8 & 0,746 & 0,244 & Valid \\
\hline 9 & 0,532 & 0,244 & Valid \\
\hline 10 & 0,530 & 0,244 & \\
\hline
\end{tabular}

Table 4. Hasil Uji Validitas Variabel $\left(\mathrm{X}_{3}\right)$

\begin{tabular}{|r|c|c|c|}
\hline Nomor Soal & rhitung & rtabel & Keterangan \\
\hline 1 & 0,326 & 0,244 & Valid \\
\hline 2 & 0,495 & 0,244 & Valid \\
\hline 3 & 0,742 & 0,244 & Valid \\
\hline 4 & 0,742 & 0,244 & Valid \\
\hline 5 & 0,587 & 0,244 & Valid \\
\hline 6 & 0,326 & 0,244 & Valid \\
\hline 7 & 0,630 & 0,244 & Valid \\
\hline 8 & 0,742 & 0,244 & Valid \\
\hline 9 & 0,538 & 0,244 & Valid \\
\hline 10 & 0,495 & 0,244 & Valid \\
\hline
\end{tabular}

Table 5. Hasil Uji Validitas Variabel (Y)

\begin{tabular}{|c|c|c|c|}
\hline Nomor Soal & rhitung & rtabel & Keterangan \\
\hline 1 & 0,430 & 0,244 & Valid \\
\hline 2 & 0,514 & 0,244 & Valid \\
\hline 3 & 0,766 & 0,244 & Valid \\
\hline 4 & 0,766 & 0,244 & Valid \\
\hline 5 & 0,645 & 0,244 & Valid \\
\hline 6 & 0,430 & 0,244 & Valid \\
\hline 7 & 0,789 & 0,244 & Valid \\
\hline
\end{tabular}




\begin{tabular}{|c|l|c|c|}
\hline Nomor Soal & rhitung & rtabel & Keterangan \\
\hline 8 & 0,766 & 0,244 & Valid \\
\hline 9 & 0,466 & 0,244 & Valid \\
\hline 10 & 0,514 & 0,244 & Valid \\
\hline
\end{tabular}

Berdasarkan tabel 2. hingga 5 sebahagian seluruh pernyataan dalam setiap variabel memiliki nilai coreccted item correlation (rhitung) lebih besar dari rtabel dan dinyatakan valid. Apabila di temukan pernyataan yang tidak valid tidak akan dilanjutkan ke pengujian reliabilitas.

\subsection{Uji Reliabilitas Data}

Reliablitas artinya memiliki sifat dapat dipercaya. Suatu alat ukur dapat dikatakan

Table 6. Hasil Uji Reliabilitas

\begin{tabular}{|c|c|c|c|}
\hline Variable & $\begin{array}{c}\text { Cronbach's } \\
\text { Alpha }\end{array}$ & $\begin{array}{c}\text { N of } \\
\text { Items }\end{array}$ & $\begin{array}{c}\text { Reabilitas } \\
\text { Status }\end{array}$ \\
\hline $\mathrm{X} 1$ & 0,834 & 10 & Reliabel \\
\hline $\mathrm{X} 2$ & 0,799 & 10 & Reliabel \\
\hline $\mathrm{X} 3$ & 0,796 & 10 & Reliabel \\
\hline $\mathrm{Y}$ & 0,839 & 10 & Reliabel \\
\hline
\end{tabular}

Dengan membandingkan hasil perhitungan yang diperoleh dengan menggunakan Cronbach Alpha, masing-masing indikator dengan standar alpha yakni 0,6, maka diketahui bahwa masingmasing indikator memiliki nilai alpha yang $(>)$ lebih besar dari 0,6. Berdasarkan hasil tersebut maka dapat disimpulkan bahwa semua indicator dari variabel yang digunakan dalam penelitian dinyatakan reliabel atau andal.

\subsection{Uji Asumsi Klasik}

\subsubsection{Uji Normalitas Data}

Pengujian normalitas data bertujuan untuk melihat normal tidaknya sebaran data yang akan dianalisis. Model regresi yang baik adalah distribusi normal atau mendekati normal. Untuk melihat normalitas data ini digunakan pendekatan grafik yaitu Normality Probability Plot.

Deteksi normalitas dengan melihat penyebaran data (titik) pada sumbu diagonal dari grafik. Menurut Santoso (2014:214), dasar pengambilan keputusan adalah:

a. Jika data menyebar disekitar garis diagonal dan mengikuti arah garis memiliki reliabilitas apabila digunakan berkalikali oleh peneliti yang sama atau peneliti lain tetap memberikan hasil yang sama (Rakhmat, 2011:17). Uji reliabilitas dengan menggunakan SPSS Versi 24.00 yang akan dilakukan menggunakan Reliability Analysis Statistic dengan Cronbach Alpha ( $\alpha)$. Jika nilai Cronbach Alpha $(\alpha)>0,60$, maka dapat dikatakan variabel tersebut reliabel. Hasil uji reliabilitas penelitian ini adalah sebagai berikut: diagonal, maka model regresi memenuhi asumsi normalitas.

b. Jika data menyebar jauh dari garis diagonal dan atau tidak mengikuti arah garis diagonal, maka model regresi tidak memenuhi asumsi normalitas. Pada output SPSS versi 24.00 bagian normal $P-P$ Plot of Regresion Standardized Residual, dapat dijelaskan bahwa data-data (titik-titik) cenderung lurus mengikuti garis diagonal sehingga data dalam penelitian ini cenderung berdistribusi normal, seperti terlihat pada gambar dibawah ini.

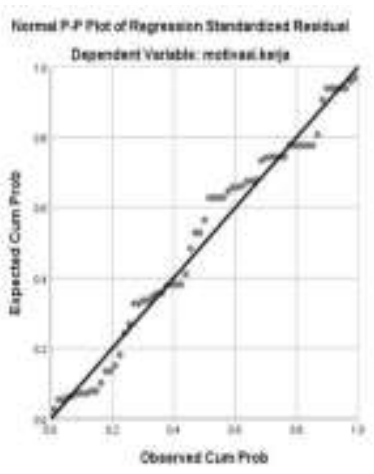

Gambar 1. Normalitas Data 


\subsubsection{Uji Multikolinearitas}

Pengujian multikolinearitas dilakukan untuk melihat apakah pada model regresi ditemukan adanya korelasi antara variabel bebas. Jika terjadi korelasi, maka dinamakan terdapat problem multikolinearitas. Cara mendeteksinya adalah dengan melihat nilai Variance Inflation Factor (VIF). Menurut Santoso (2014:203), pada umumnya jika VIF lebih besar dari 5, maka variabel bebas tersebut mempunyai persoalan multikolinearitas dengan variabel bebas lainnya.

Pada ouput SPSS bagian Coefficient, semua angka VIF berada dibawah 5, hal ini menunjukan tidak terjadi multikolinearitas, seperti dapat dilihat pada tabel dibawah ini.

Tabel 7. Uji Multikolinearitas

\begin{tabular}{|c|c|c|c|}
\hline \multicolumn{4}{|c|}{ Coefficients ${ }^{\mathbf{a}}$} \\
\hline & & Tolerance & VIF \\
\hline \multirow[t]{4}{*}{1} & \begin{tabular}{|l} 
(Constant) \\
\end{tabular} & & \\
\hline & pelatihan & .793 & 1.261 \\
\hline & fasilitas & .817 & 1.224 \\
\hline & kompensasi & .699 & 1.431 \\
\hline
\end{tabular}

\subsubsection{Uji Heteroskedastisitas}

Pengujian heteroskedastisitas bertujuan untuk melihat apakah dalam sebuah model regresi terjadi ketidaksamaan varians dari residual yang merupakan suatu pengamatan ke pengamatan yang lainnya. Jika varians dari residual yang merupakan suatu pengamatan ke pengamatan yang lain bernilai tetap, maka hasil data disebut homoskedastisitas dan jika varians berbeda atau bernilai tidak tetap maka disebut heteroskedastisitas. Model regresi yang baik adalah model yang bernilai tetap atau homoskedastisitas atau tidak terjadi heteroskedastisitas.

Deteksi heteroskedastisitas dilakukan dengan cara melihat ada tidaknya pola tertentu pada data yang diolah. Menurut Santoso
(2014:208), dasar pengambilan keputusannya adalah:

a. Jika pola tertentu seperti titik-titik yang ada membentuk suatu pola tertentu yang teratur, maka terdapat situasi heteroskedastisitas.

b. Jika tidak ada pola yang jelas, serta titik-titik menyebar diatas dan dibawah angka nol pada sumbu Y, maka tidak terjadi

heteroskedastisitas.

Pada output SPSS dibagian Scatrerplot, terlihat titk-titik menyebar secara acak, tidak membentuk sebuah pola tertentu yang jelas, serta tersebar baik diatas maupun dibawah angka nol pada sumbu Y. Hal ini berarti tidak terjadi heterskedastisitas pada model regresi, sehingga model regresi layak dipakai. Pola Scatterplot dapat dilihat pada gambar dibawah ini.

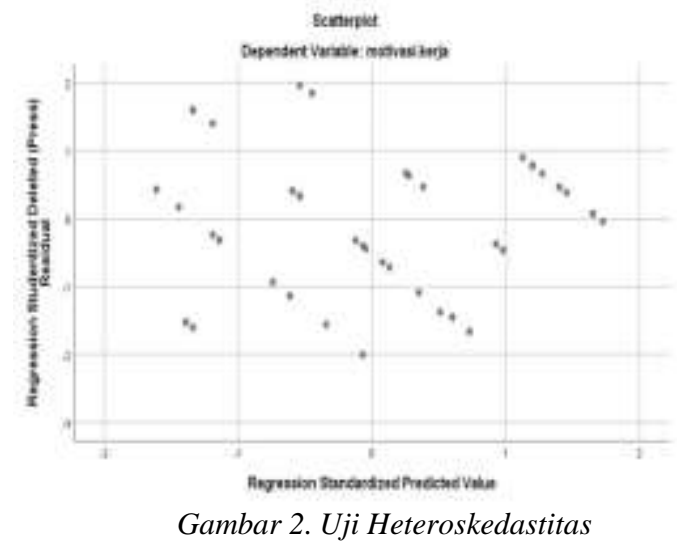

\section{Evaluasi Data (Analisa Regresi Linier Berganda )}

\subsection{Pengujian Hipotesis}

Dalam evaluasi data ini penulis akan melakukan pengujian hipotesis, baik secara partial ataupun secara simultan. Selanjutnya untuk mempermudah dalam evaluasi data ini, maka penulis mencari niali-nilai yang dibutuhkan dengan menggunakan perangkat lunak komputer yaitu program SPSS V.24.00 for windows dengan hasil data sebagai berikut:

Tabel 8. Hasil Uji Statistik Keofesien Regresi

\section{Coefficients $^{\mathbf{a}}$}

Unstandardized Coefficients

Model

B Std. Error

Standardized

Coefficients Beta

\begin{tabular}{ll|r|r|r|r}
\cline { 2 - 7 }$($ Constant $)$ & 3.319 & 3.549 & .935 & .353 \\
\hline pelatihan & .394 & .071 & .431 & 5.561 & .000 \\
\hline fasilitas & .321 & .069 & .355 & 4.652 & .000 \\
\hline kompensasi & .269 & .070 & .318 & 3.847 & .000 \\
\hline
\end{tabular}

a. Dependent Variable: motivasi.kerja 
Berdasarkan tabel 5.12 diatas dapat dibuat persamaan regresi sebagai berikut:

$$
\begin{gathered}
\mathrm{Y}=3,319+0,394 \mathrm{X} 1+0,321 \mathrm{X} 2+ \\
0,269 \mathrm{X} 3+\varepsilon
\end{gathered}
$$

Persamaan diatas dijelaskan bahwa koefesien pelatihan mempunyai nilai positif yaitu 0,394, hal ini menunujukan bahwa variabel pelatihan mempunyai pengaruh positif terhadap motivasi kerja.

Berdasarkan persamaan diatas bahwa koefesien fasilitas memiliki nilai positif yaitu 0,321 . Hal ini menunjukan bahwa variabel fasilitas mempunyai pengaruh positif terhadap motivasi kerja.

Berdasarkan persamaan diatas bahwa koefesien kompensasi memiliki nilai positif yaitu 0,269 . Hal ini menunjukan bahwa variabel kompensasi juga mempunyai pengaruh positif terhadap motivasi kerja.

\subsection{Pengujian Secara Simultan (Uji F)}

Untuk melihat hasil seberapa besar pengaruh yang di berikan variabel independen terhadap dependen secara simultan ( bersama-sama) pada penelitian ini maka dapat di jelaskan pada tabel di bawah ini :

Tabel 9. Hasil Uji Statistik Secara Simultan

\begin{tabular}{llllllll}
\multirow{2}{*}{$\begin{array}{c}\text { Model } \\
1\end{array}$} & \multicolumn{9}{c}{ Sum of Squares df } & ean Square & F & Sig. \\
\cline { 2 - 7 } & Regression & 62.571 & 3 & 20.857 & 49.611 & $.000 \mathrm{~b}$ \\
\cline { 2 - 7 } & Residual & 25.645 & 61 & .420 & & \\
\cline { 2 - 7 } & Total & 88.215 & 64 & & & \\
\hline
\end{tabular}

a. Dependent Variable: motivasi.kerja

b. Predictors: (Constant), kompensasi, fasilitas, pelatihan

Pada tabel 9 diatas terlihat bahwa nilai Fhitung adalah 49,611 dan nilai signifikansi 0,000. Diketahui nilai Ftabel dengan tingkat kepercayaan 95\% $(\alpha: 0,05)$ adalah 2,740. Oleh karena itu nilai Fhitung > Ftabel $(49,611$ $>$ 2,740 ) maka $\mathrm{H}_{\mathrm{O}}$ ditolak dan menerima hipotesis dalam penelitian ini yaitu bahwa pelatihan, fasilitas dan kompensasi secara simultan berpengaruh positif dan signifikan terhadap motivasi kerja pegawai Badan Pengelola Keuangan Dan Aset Daerah Kabupaten Batu Bara.

\subsection{Pengujian Secara Parsial (Uji t)}

Tabel 10. Hasil Uji Parsial Variabel X Terhadap Y

\begin{tabular}{|c|c|c|c|c|c|c|}
\hline \multirow{2}{*}{\multicolumn{4}{|c|}{ Unstandardized Coefficients }} & \multirow{3}{*}{$\begin{array}{c}\text { Standardized } \\
\text { Coefficients Beta }\end{array}$} & \multirow{3}{*}{$\mathrm{t}$} & \multirow{3}{*}{ Sig. } \\
\hline & & & & & & \\
\hline \multicolumn{2}{|c|}{ Model } & B & Std. Error & & & \\
\hline \multirow[t]{4}{*}{1} & (Constant) & 3.319 & 3.549 & & .935 & .353 \\
\hline & pelatihan & .394 & .071 & .431 & 5.561 & .000 \\
\hline & fasilitas & .321 & .069 & .355 & 4.652 & .000 \\
\hline & kompensasi & .269 & .070 & .318 & 3.847 & .000 \\
\hline
\end{tabular}

Coefficients ${ }^{\mathbf{a}}$

a. Dependent Variable: motivasi.kerja

\subsection{Pengaruh Pelatihan Terhadap Motivasi Kerja}

Untuk mengetahui secara parsial pengaruh pelatihan terhadap motivasi kerja pegawai dapat dilihat pada tebel 5.14 diatas. Berdasarkan tabel tersebut diperoleh nilai thitung sebesar 5,561 dan nilai signifikansi 0,000 . Sedangkan nilai ttabel pada tingkat kepercayaan 95\% $(\alpha: 0,05)$ adalah 2,000. Oleh karena itu nilai thitung > ttabel $(5,561>2,000)$ maka Ho ditolak dan menerima hipotesis dalam penelitian ini bahwa pelatihan secara parsial berpengaruh positif terhadap motivasi kerja pegawai Badan Pengelola Keuangan Dan Aset Daerah Kabupaten Batu Bara. 


\subsection{Pengaruh Fasilitas Terhadap Motivasi Kerja}

Untuk mengetahui secara parsial pengaruh fasilitas terhadap motivasi kerja pegawai, dapat dilihat pada tebel 5.14 diatas. Berdasarkan tabel tersebut diperoleh nilai thitung sebesar 4,562 dan nilai signifikansi 0,000 . Sedangkan nilai tabel pada tingkat kepercayaan $95 \%(\alpha: 0,05)$ adalah 2,000. Oleh karena itu nilai thitung > tabel $(4,562>2,000)$ maka $\mathrm{H}_{\mathrm{O}}$ ditolak dan menerima hipotesis dalam penelitian ini bahwa fasilitas secara parsial berpengaruh positif terhadap motivasi kerja pegawai Badan Pengelola Keuangan Dan Aset Daerah Kabupaten Batu Bara.

\subsection{Pengaruh Kompensasi Terhadap Motivasi Kerja}

Untuk mengetahui secara parsial pengaruh kompensasi terhadap motivasi kerja pegawai, dapat dilihat pada tebel 5.14 diatas. Berdasarkan tabel tersebut diperoleh nilai thitung sebesar 3,847 dan nilai signifikansi 0,000 . Sedangkan nilai ttabel pada tingkat kepercayaan 95\% ( $\alpha$ : $0,05)$ adalah 2,000. Oleh karena itu nilai thitung > tabel $(3,847>2,000)$ maka $\mathrm{Ho}_{0}$ ditolak dan menerima hipotesis dalam penelitian ini bahwa kompensasi secara parsial berpengaruh positif terhadap motivasi kerja pegawai Badan Pengelola Keuangan Dan Aset Daerah Kabupaten Batu Bara.

\subsection{Uji Koefisien Determinasi $\left(\mathbf{R}^{\mathbf{2}}\right)$}

Uji determinan adalah uji yang dilakukan untuk mengetahui seberapa besar pengaruh variabel independent (pelatihan, fasilitas dan kompensasi) terhadap variabel dependent (motivasi kerja). Untuk melihat hasil uji determinan maka dapat diketahui nili R Square atau koefesien determinasi dan dapat dilihat dibawah ini.

\begin{tabular}{|c|c|c|c|c|c|}
\hline \multirow{3}{*}{ Model } & \multirow{3}{*}{$\mathrm{R}$} & \multirow{3}{*}{ R Square } & \multicolumn{3}{|l|}{$\begin{array}{c}\text { Tabel 11. Model Summary } \\
\text { Model Summaryb }\end{array}$} \\
\hline & & & Adjusted R Std. Error of the & \multicolumn{2}{|c|}{ Change Statistics } \\
\hline & & & Estimate & $\begin{array}{l}\text { R Square } \\
\text { Change }\end{array}$ & F Change \\
\hline$\overline{1}$ & $.842 \mathrm{a}$ & .709 & .64839 & .709 & 49.611 \\
\hline
\end{tabular}

Nilai R Square pada tabel 1. diatas adalah 0,709 . Hal ini menunjukan bahwa $70,90 \%$ variabel motivasi kerja pegawai Badan Pengelola Keuangan Dan Aset Daerah Kabupaten Batu Bara dapat di jelaskan oleh variabel pelatihan, fasilitas dan kompensasi sedangkan sisanya sebesar $29,10 \%$ di dijelaskan oleh variabel lain yang tidak di teliti.

\section{Kesimpulan}

a. Pelatihan secara parsial berpengaruh positif terhadap motivasi kerja pegawai Badan Pengelola Keuangan Dan Aset Daerah Kabupaten Batu Bara

b. Fasilitas secara parsial berpengaruh positif terhadap motivasi kerja pegawai Badan Pengelola Keuangan Dan Aset Daerah Kabupaten Batu Bara

c. Kompensasi secara parsial berpengaruh positif terhadap motivasi kerja pegawai Bada Pengelola Keuangan Dan Aset Daerah Kabupaten Batu Bara d. Pelatihan, fasilitas dan kompensasi secara simultan berpengaruh positif dan signifikan terhadap motivasi kerja pegawai Badan Pengelola Keuangan Dan Aset Daerah Kabupaten Batu Bara

e. Dengan nilai R Square sebesar 0,709, ini menunjukan bahwa $70,90 \%$ variabel motivasi kerja pegawai Badan Pengelola Keuangan Dan Aset Daerah Kabupaten Batu Bara dapat di jelaskan oleh variabel pelatihan, fasilitas dan kompensasi sedangkan sisanya sebesar $29,10 \%$ di dijelaskan oleh variabel lain yang tidak di teliti

\section{DAFTAR PUSTAKA}

Azwar, S. 2017. Metode Penilitan. Yogyakarta: Pustaka Pelajar.

Cascio, Wayne F. 2010. Managing Human Resources. Colorado: Mc Graw-Hill. Cooper, Donald R and Pamela S. Schlindler. 2011. Metode Riset Bisnis, Volume 1 Edisi 
Sembilan, Alih Bahasa Budijanto dkk. McGraw-Hill Irwin. Jakarta.

Dessler, Gerry. 2017. Manajemen Sumber Daya Manusia. Jakarta: Indeks. Djoyowirono. 2015. Manajemen Suatu Paradigma. Edisi keempat. Yogyakarta : BPFE.

Drucker, Peter.F, 2015. Manajemen: Tugas, Tanggung Jawab dan Praktek. Jakarta: PT Gramedia.

Faisal, Mohammad Amir. 2015. Memahami Evaluasi Kinerja Karyawan, Konsep, dan Penilaian Kinerja di Perusahaan. Jakarta: Mitra WacanaMedia.

Gomes, F. C. 2012. Manajemen Sumber Daya Manusia, Edisi revisi. Yogyakarta: Andi Offset.

Handoko, T. Hani. 2010. Manajemen Sumber Daya Manusia, Edisi Kedua, Cetakan Ketigabelas. Yogyakarta: BPFE.

Hanggraeni, Dewi. 2012. Manajemen Sumber Daya Manusia. Jakarta: Lembaga Penerbit Fakultas Ekonomi Universitas Indonesia.

Hartanto. 2010. Organisasa \& Manajemen Sumber Daya Manusia. Bandung : Alfabeta.

Hartanto. Amin Nur. 2015. Nilai - Nilai Manajemen Pendidikan. Bandung : Alfabeta.

Hasibuan, Malayu S.P. 2011. Manajemen Sumber Daya Manusia. Jakarta: Bumi Akasara. 2012. Organisasi dan

Motivasi. Jakarta: Bumi Akasara.

Herzberg, L. G. , \& Alutto, J. A. 2011. Personal and role-related factors in the development of organizational commitment. Administrative Science Quarterly, 17 (4), 555-573.

Husnan, Saud. 2012. Dasar - Dasar Manajemen. Yogyakarta : UPP STTIM YKPN.

Lupiyaodi, Rambat. 2012. Manajemen Pemasaran Jasa. Jakarta : Salemba Empat.

Mangkunegara, A.P. 2012. Evaluasi Kinerja Sumber Daya Manusia. Bandung: Remaja Rosdakarya.

Mangkuprawira, Sjafri. 2014. Manajemen Sumber Daya Manusia Strategik. Bogor: Ghalia Indonesia.

Mathis, Robert L. dan Jackson, John H. 2012. Manajemen Sumber Daya Manusia Edisi
9, dialih bahasakan oleh Jimmy Sadeli dan Bayu Prawira Hie. Jakarta: Salemba Empat.

Mondy R Wayne. 2018. Manajemen Sumber

Daya Manusia. Jakarta: Erlangga. Narimawati, Umi. 2016. Riset Manajemen Sumber Daya Manusia Aplikasi \& Contoh Perhitunganya. Jakarta. Agung Media.

Nitisemito, Alex S. 2011. Manajemen Personalia. Jakarta: Ghalia Indonesia. Notoadmodjo, $\quad$ Soekidjo. 2010. Pengembangan Sumber Daya Manusia. Jakarta: Rineka Cipta.

Nursalam. 2017. Konsep Dan Penerapan Metodologi Penelitian Ilmu pendidikan. Edisi 2. Jakarta : Salemba Medika.

Riva'i, Veithzal. 2014. Manajemen Sumber Daya Manusia. Jakarta: PT. Raja Grafindo Persada.

Robbins, Stephen P \& Mary Coulter. 2014. Manajemen Jilid 1/ Stephen P Robbins dan Mary Coulter diterjemahkan oleh Bob Sabran, Wibi Hardani. - Ed.10, Cet13-. Jakarta: Erlangga.

Robbins, Stephen P. 2011. Perilaku Organisasi. Jakarta: Salemba Empat. Simamora, Henry. 2013. Manajemen Personalia. Yogyakarta: STIE YKPN Yogyakarta.

2014.

Manajemen Sumber Daya Manusia.

Yogyakarta: STIE YKPN Yogyakarta.

Sinambela, Lijan Poltak. 2016. Manajemen Sumber Daya Manusia: Membangun Tim Kerja yang Solid untuk Meningkatkan Kinerja. Jakarta: Bumi Aksara.

Singarimbun, M dan Efendi. 2012. Metode Penelitian Survey. Jakarta: PT. Pustaka LP3ES.

Soekidjo, Notoadmodjo. 2017. Pengembangan

Sumber Daya Manusia. Jakarta: Rineka Cipta.

Sofyan, Hanafi. 2011. Manajemen Sumber Daya Manusia. Jakarta: Elex Media Komputindo.

Suarli \& Bahtiar. 2010. Manajemen pendidikan dengan Pendekatan Praktis. Erlangga

Sumodiningrat. 2011. Pengantar Statistika. Jakarta: Andi.

Sunyoto, Agus. 2012. Manajemen Sumber Daya Manusia. Jakarta: IPWI. Sunyoto, Danang. 2012. Manajemen Sumber Daya Manusia. Jakarta: PT. Buku Seru. 
Thoha, Miftah. 2012. Kepemimpinan Dalam Manajemen. Jakarta: PT. Raja Grafindo Persada.

Torang, Syamsir. 2013. Metode Riset Struktur \& Perilaku Organisasi. Bandung: Alfabeta.

Trenggono. 2018. Metode Penelitian Manajemen. Jakarta: Rajawali Pers. Wibowo. 2011. Budaya Organisasi. Jakarta: PT. Raja Grafindo Persada.

2012. Manajemen Kinerja. Jakarta: PT. Raja Grafindo Persada.

Zainal, Arifin. 2014. Evaluasi Pembelajaran Manajemen. Jakarta: PT. remaja Rosda Karya. 